\title{
A Study of Physical Education Promotion Plan for the Young Men's Association by "HOTOKUKAI" in the Early Taisho Era: An Analysis of the “SHIMIN" Bulletins"
}

\author{
Yuta Ono $^{1}$, Hidenori Tomozoe ${ }^{1}$, and So Nemoto ${ }^{2}$ \\ ${ }^{1}$ Faculty of Sport Sciences, Waseda University \\ 2-579-15 Mikajima, Tokorozawa, Saitama 359-1192, Japan \\ y-ono.sps@aoni.waseda.jp \\ 2Ikuei Junior College \\ 1656-1 Kyomemachi, Takasaki, Gunma 370-0011, Japan
}

\begin{abstract}
*Original article published in Japan J. Phys. Educ. Hlth. Sport Sci. 61: 701-716, 2016 (in Japanese)
[Received August 7, 2018; Accepted March 29, 2019; Published online April 9, 2019]
\end{abstract}

\begin{abstract}
This study focuses on the Hotokukai, an auxiliary organization of the Ministry of Home Affairs, and aims to clarify the concept of the promotion of physical education for the Young Men's Association planed by the Hotokukai. First, the Hotokukai sought to encourage physical education for young people to cultivate physical strength and contribute to manual labor. Characteristic of the view of physical education in Hotokukai youth education was the encouragement of physical education that benefitted lives through the link between labor and physical education. To investigate methods of encouraging physical education, the Hotokukai held conferences on matters to be executed with respect to such encouragement. The conferences were attended by Hotokukai trustees and external experts on physical education, education, and medicine. Finally, the Hotokukai compiled the results of these conferences and published matters to be executed with respect to encouraging physical education in Shimin. These matters to be executed listed details of concepts related to physical education for the citizens of the country and physical education in schools, as well as concepts to encourage physical education in the Young Men's Association.
\end{abstract}

Keywords: Ministry of Home Affairs, young working men, local improvement movement, character building, sport pedagogy

\section{Introduction}

\subsection{About the Young Men's Association}

The Young Men's Association (YMA)*1 is a social education organization that was developed during the late Meiji and Taisho periods*2, in accordance with directives from the Ministry of Home Affairs and other state agencies, with the aim of providing local projects and supplemental education for young men engaged in manual labor, usually after having completed compulsory education. It increasingly took on a state-organized character, following an important directive issued by the
Ministries of Home Affairs and of Education in 1915, known as the directive "on the Development of YMA teaching", (the first directive) (Kumagai, 1942).

The YMA attached importance to physical education and sports activities from the Taisho period (1912-1926) onward. The YMA's physical education and sports activities were actively promoted, in connection with young men's admittance to the national system and other social circumstances within a context of physical ability enhancement and ideological issues, as well as military education issues. Previous studies have pointed out that physical education and sports promotion in the YMA 
was one factor stimulating the spread and promotion of physical education and sports in the population at large as of the Taisho period (Kinoshita, 1970; Kozu, 1994; Ono and Tomozoe, 2014; Sasaki, 2000, 2004; Takenoshita and Kishino, 1959).

The YMA's physical education and sports activities also played an important role in the state's efforts to achieve national integration. For example, the YMA offered organizational support for the Meiji Jingu Athletic Meeting that started in 1924, and it has been suggested that this contributed to the meet's later development (Irie, 1991). It has also been pointed out that the YMA was used to promote various national physical education promotion projects for ideological control and during the war (Kinoshita, 1970; Sasaki, 2000). This suggests that the promotion of physical education in the YMA and sports activities can be framed as a foothold for the national integration that spread during and after the Taisho period. If we consider the role played by the YMA in the development of national physical education and sports during the Showa prewar period, the importance of the YMA's various forms of involvement in physical education and sports becomes self-evident.

\subsection{A survey of previous studies}

Looking at the process through which the promotion of physical education in the YMA was introduced, previous studies have suggested that Tanaka Giichi (Tanaka) of the Army Ministry was actively involved in the issuance of the first directive and that it strongly reflected Tanaka's ideas (Kinoshita, 1970; Kozu, 1994; Ono and Tomozoe, 2015; Takenoshita and Kishino, 1959). According to Takenoshita and Kishino (1959), Tanaka began to advocate a reorganization of Japan's youth and the importance of physical education following his inspection of Western countries in 1914, during which he was deeply impressed by German youth education efforts, as that country was gearing up for war.

Furthermore, studies have clarified the important role played by the Ministry of Home Affairs and its bureaucrats in the development of the promotion of physical education in the YMA (Kisnoshita, 1970; Ono and Tomozoe, 2015; Takenoshita and Kishino, 1959). It has been pointed out that the Ministry of Home Affairs was directly involved in the YMA's physical education guidance (Takenoshita and Kishino, 1959) and took an interest in the promotion of physical education in the YMA, especially from the standpoint of maintaining public order at home (Kinoshita, 1970).

In particular, Ono and Tomozoe (2015) clarified how the YMA's physical education promotion policy was realized under the leadership of Governor Inoue Tomoichi (Inoue) in Tokyo, following the issuance of the first directive. This study showed how, as a Home Affairs bureaucrat, the governor*3 played a principal role in implementing*4 YMA policy.

These circumstances suggest that both the Army Ministry and the Ministry of Home Affairs were involved in various debates about the promotion of physical education in the YMA. The debate ${ }^{* 5}$ carried out within the Ministry of Home Affairs is likely to have influenced the contents of the first directive and the development of the YMA's physical education and sports activities. Even so, all preceding studies have been content to provide general outlines of the ministry's intentions and vision of the promotion of physical education in the YMA without sufficiently elucidating the details.

\subsection{This study's perspective and aims}

The "Hotokukai",*6 provides important hints to taking on this task. Details will follow, but for now it is enough to know that the Hotokukai was an indoctrination organization established on the initiative of Home Affairs bureaucrats in 1906 as a parent organization promoting the local improvement movement. Most of the Hotokukai's trustees were bureaucrats or businesspeople with strong links to the Ministry of Home Affairs. Because of this, the Hotokukai was seen as a de facto "auxiliary organization to the Ministry of Home Affairs" (Oshima, 1959, p. 107) that functioned as a "flying column" for implementing the ministry's local improvement movement (Kano, 1964).

The Hotokukai was not composed entirely of Home Affairs bureaucrats. Thus, we should be careful not to assume that the intentions of the Hotokukai were fully aligned with the intentions of the Ministry of Home Affairs. Nevertheless, as shown above, the Hotokukai organization was integrated with the Ministry of Home Affairs and a parent organization to promote the local improve- 
ment movement. In fact, the aforementioned Inoue was a central figure in the Hotokukai, and there was no shortage of other trustees who also served as governors. ${ }^{* 7}$

In addition, the Hotokukai established the YMA's central department by making its youth department a head organization of the YMA nationwide in January 1916. It then detached and made the department independent in November of the same year. This was carried on by the Nippon Seinenkan foundation in September 1921. In other words, the Hotokukai can be seen as a predecessor to the nationwide YMA's head organization. The individuals discussed in this paper also went on to become central leaders of the national YMA. Trends within the Hotokukai provide hints to elucidate the intentions and vision of the Ministry of Home Affairs and related individuals with respect to the promotion of physical education in the YMA and shed light on the intentions and vision of those in teaching positions in the subsequent national YMA.

Hence, this paper examines the Hotokukai's vision for the promotion of physical education in the YMA with the aim of elucidating how the promotion of physical education in the YMA was debated within the Ministry of Home Affairs and how that debate was actualized. The paper is structured as follows. Before getting into the central discussion, I outline the local improvement movement and the Hotokukai organization. I then clarify the following three points as the paper's concrete themes: the Hotokukai's aims for its youth education; the role of physical education in the Hotokukai's youth education; and the concrete contents of the Hotokukai's vision for the promotion of physical education in the YMA, based on an examination of the Hotokukai's "Executive Council for the Promotion of Physical Education" and "Executive Matters for the Promotion of Physical Education."

As stated above, preceding studies have suggested that the Ministry of Home Affairs and Home Affairs bureaucrats played an important role in the development of physical education promotion in the YMA. Thus, the significance of closely examining the intentions and vision of both the Army Ministry and the Ministry of Home Affairs is evident.

To go one step further, the Ministry of Home Affairs went on to active involvement in the Meiji Jingu Athletic Meeting and a variety of other forms of physical education and sports administration during and after the Taisho period. This paper also aims to use its examination of the vision of physical education promotion in the YMA to clarify the Ministry of Home Affairs' perception of and expectations for physical education and sports during the period from the Russo-Japanese War to the end of the Taisho period.

\section{Research method: A study of the Hotokukai Shimin bulletin}

A principal activity of the Hotokukai was the publication of its bulletin, Shimin. Shimin was published over 38 years from April 1906 to September 1944. Most of the publication costs were covered by donations from businessperson trustees, including the executive director of Mitsui Bank, Hayakawa Senkichiro (Hayakawa), and the president of the Japan Sugar Refining Company, Suzuki Tozaburo (Tomeoka, 1922).

The objective of launching Shimin was "to find the latest modern expertise by searching broadly in Japan and abroad through business systems to further arouse our general disposition, render management autonomous, develop education, and enrich national manpower, as well as introduce these materials researched by us to the world" (Hotokukai, 1906a, p. 3). As suggested by this aim, Shimin was not simply a bulletin introducing the activities of the Hotokukai but a scholarly publication organized around papers researched by the trustees.

Responsible for the planning and editing of Shimin were Home Affairs bureaucrats like Inoue, who served as prefectural chief of the Local Bureau of the Ministry of Home Affairs when the bulletin was launched, and Ichiki Kitokuro (Ichiki), director of the Legislative Bureau of the Ministry of Home Affairs. The articles were written primarily by Home Affairs bureaucrats but also by bureaucrats from the Ministry of Education, the Ministry of Agriculture and Commerce, and other ministries, as well as businesspeople, social activists, and others. Moreover, many of the readers were municipal mayors, Diet members, people involved in local administrations, and elementary school teachers (Sakata, 1972). Inoue said, "I cannot be anything else but truly happy when Shimin is praised as a chain that binds together the three Ministries of 
Home Affairs, Education, and Agriculture and Commerce, as well as local personages" (Inoue, 1916, p. 13), and so Shimin can be said to have been a tool to guide national indoctrination, functioning as "an intermediary between the center and the provinces" (Inoue, 1916, p. 13). From this, we may conclude that Shimin made a significant contribution to linking the Ministry of Home Affairs with prominent figures outside of government (Fuwa, 1990).

What is the significance of this paper, using Shimin as its principal source material? As previously discussed, the planning and editing of Shimin was handled primarily by Home Affairs bureaucrats, which means that the articles reflected, to a large extent, the intentions of those bureaucrats. In fact, Shimin has frequently been referenced by past studies on the history of domestic policy focusing on the Showa prewar period. It has been evaluated as "an indispensable primary source for research on the policies and development of the Ministry of Home Affairs"' (Sakata, 1972, p. 2). Also, it has been said that "the contents discussed in Shimin really became the principles of the local improvement movement, while the papers in Shimin serve to clarify what the local improvement movement was doing"' (Namimatsu, 2004).

This is precisely why Shimin is an important primary source for spelling out what was debated within the Ministry of Home Affairs with respect to the promotion of physical education in the YMA and how that debate was actualized. Shimin recorded specifics about how Home Affairs bureaucrats attempted to overcome a variety of domestic policy issues as they related to the local improvement movement. In other words, Home Affairs bureaucrats debated in Shimin the reorganization of the YMA and their expectations for physical education, based on their connections to domestic policy issues. As such, it is likely that the expectations for YMA physical education debated in Shimin distinctly reflected the intentions of the Ministry of Home Affairs. This is why it is so meaningful for this study to use Shimin as its primary source and the reason I analyzed the trustees' assertions as they appeared in Shimin.

Furthermore, the period under study is from 1906, when the Hotokukai was founded and Shimin was launched, to around 1915, when the Hotokukai proposed the "Executive Matters for the Promotion of Physical Education" as its vision for the promotion of physical education in the YMA.

\section{The local improvement movement and the Hotokukai}

Preceding studies have shown that policy debates in the Ministry of Home Affairs in the period following the end of the Russo-Japanese War and throughout the early Taisho period were influenced by the local improvement movement and Hotokuism (Oshima, 1998). We may surmise that the Hotokukai's vision for the promotion of physical education in the YMA can likewise be derived from the context of the local improvement movement and Hotoku-ism.

Thus, I would first like to provide an overview of the local improvement movement and Hotoku-ism in this section, as a preamble to my examination of the Hotokukai's vision of the promotion of physical education in the YMA. I will then clarify the Hotokukai's aims for its youth education in the next section and go on to concretely examine its vision for the promotion of physical education.

\subsection{About the local improvement movement}

Japan became a major military power during the First Sino-Japanese War (1894-1895) and RussoJapanese War (1904-1905) and discovered a need to enhance its international routes in a bid to succeed in foreign markets as it competed with other developed countries (Ishida, 1954; Miyaji, 1973; Oe, 1974). At the same time, attempts at extensive reorganization were made domestically to adapt the domestic social system to imperialism and prepare for future wars. This was coupled with the need to deal with the domestic disorder in the wake of the Russo-Japanese War by restoring municipal finances and the basis of the national livelihood, and by constructing a system of national unity (Fuwa, 1990; Miyaji, 1973). Local improvement was a state-organized movement spearheaded by the Ministry of Home Affairs to deal with such social issues, following the Russo-Japanese War.

Implemented as of 1905, the local improvement movement was a measure for national integration aimed at restoring public finances, which had collapsed under the weight of enormous war expenditures, and unifying through nationalism popular 
sentiment, which was in turmoil from intensifying social contradictions and dissatisfaction with the peace (Miyaji, 1973). The local improvement movement did not simply seek to strengthen state control over local administration but to indoctrinate villagers through a variety of activities such as courses organized by various private and semigovernmental organizations, public recognition, and the presentation of exemplary models of behavior.

A characteristic of the local improvement movement was that it organized the YMA, the Young Women's Association, and other national indoctrination activities for the purpose of fostering a population that would be willing to cooperate with and submit to policy implementation (Local Bureau of the Ministry of Home Affairs, eds., 1911). Of these, the YMA was prioritized as a way to incorporate the natural energy of the villages' young men into the state's power structure.

\subsection{The Hotokukai's organization and Hotoku- ism}

The Hotokukai was an indoctrination organization established in 1906 on the initiative of Home Affairs bureaucrats like Inoue and Ichiki as a parent organization to promote the local improvement movement. It was created "to arouse a national tradition of sincerity and diligence and a spirit of cooperation and solidary sharing, as well as to seek coordination and unity, reform and development in all areas of morality, economics, local autonomy, and education"' (Hotokukai, 1906a, p. 1). The organization was managed primarily by the trustees. ${ }^{* 8}$

Why did the Ministry of Home Affairs establish the Hotokukai as a parent organization to promote the local improvement movement? Ichiki, who played a central role in the establishment of the Hotokukai, recalls that time with the following words:

For the sake of advancing our nation's postwar fortune, we had no choice but to increase our economic strength, and more immediately, there was a need to somehow repay our two-billion-yen national debt. At the same time, the world of finance was running the risk of being subjected to various abuses, so we wanted to create a balance between morality and eco- nomics, arouse a spirit of so-called solidary sharing, thus remedying the faults of economic development and doing away with surviving abuses. This is why we gathered likeminded individuals $[\ldots]$ and paved the way for the present. (Ichiki, 1920, p. 8)

After the end of the Russo-Japanese War, Japan advanced its position in the world and strived to build an imperialist state, which required a domestic foundation that could forcefully stimulate the wars of the coming generation. It was in the context of such social conditions that the Hotokukai had to strengthen its economic base on the national level, as well, to help in "advancing our nation's [...] fortune."

Thus, Tomeoka Kosuke (Tomeoka), who, like Ichiki, played a central role in the establishment of the Hotokukai as a representative of the Ministry of Home Affairs, said about the motive for its founding, "I had been studying Master Ninomiya Sontoku since around 1903, and I felt that his teachings were the most apt for harmonizing morality and economics [...]. I saw it as conforming to the demands placed on us by the times" (Tomeoka, 1914, pp. 38-39). Tomeoka believed that Ninomiya's teachings provided a sound philosophy to address the managerial problem in the postwar period and establish the Hotokukai for the purpose of morally indoctrinating the nation.

The teachings to which Tomeoka referred encompassed the "Hotoku thought"*9 advocated by Ninomiya Sontoku (Ninomiya). The core ideology of the Hotokukai was "Hotuku-ism," which was based on Ninomiya's "Hotoku thought." It has been suggested that the "Hotoku-ism" advocated by the Hotokukai was the "Hotoku thought" of Ninomiya, layered with new interpretations to adapt it to postwar social realities (Hayata, 2014; Namimatsu, 2004; Oshima, 1959). At the time, Ninomiya was already perceived as a restorer of early-modern agriculture, and it was not seen as realistic to directly apply his ideas to late Meiji period (1868-1912) modern society (Inoue, 1909; Suzuki, 1909). Thus, the Hotokukai planned to spread its Hotoku-ism as an ideology that could be applied not only to agricultural society but broadly, to all facets of Japanese society.

Next, with respect to the specifics of Hotoku-ism, the Hotokukai stated, "roughly speaking, it con- 
sists of these two: One is the nation's moral dynamism and the other is the nation's economic dynamism" (Hotokukai, 1906a, p. 1). "Moral dynamism" referred to carrying out one's work to the best of one's ability, doing one's duty, and overcoming challenges, regardless of one's socioeconomic status; this was understood to both benefit oneself and contribute to the joy of society as a whole (Hotokukai, 1906a). By contrast, "economic dynamism" was about "diligence," which is the individual effort to improve oneself while passionately engaging in economic activities, and how it led to increases in social benefit and public welfare (Hotokukai, 1906a).

The Hotokukai appreciated harmony between moral and economic dynamism as the basis of social stability, stating that, "These two elements of moral and economic dynamism are both remarkably vigorous, and there are, especially, harmony and maturity developing in their relation", (Hotokukai, 1906a, p. 2). It was from this line of thought that the trustees adopted the slogan "Moral and Economic Harmony" (Ichiki, 1907, p. 19; Tomeoka, 1914, p. 38) and sought to inspire Hotoku-ism.

In summary, Hotoku-ism pivoted around "Moral and Economic Harmony" and can be seen as an ideology that inspired a spirit of communal unity and diligence. Thus, this ideology was taken to be the basic ideology of the Ministry of Home Affairs in the period after the Russo-Japanese War and throughout the early Taisho period (Taikakai, 1971). The Hotokukai adopted Hotoku-ism as its core ideology and sought to improve local finances to build a stable domestic system, while stimulating spontaneous obedience and cooperation among municipal residents.

\section{The Hotokukai's aims for its youth educa- tion}

How did the Hotokukai's trustees perceive youth education in the context of the local improvement movement? First, Local Bureau Municipal Chief Nakagawa Nozomu (Nakagawa), a trustee responsible for the management and guidance of local improvement project courses $* 10$ with the Ministry of Home Affairs, stated the following about the aims of youth education:
The discipline of boys and young men, the successors of the future, ought to be viewed as tremendously important. If we wish to reform the people's hearts by inspiring a tradition of sincerity and diligence, endeavor to awaken public spirit and elicit cooperation, and thus develop local autonomy and enable national prosperity, then we must start by disciplining the youth who are the foundation. (Nakagawa, 1908, p. 16)

According to Nakagawa, the development of local autonomy in Japan was anticipated by young men who inspired "a tradition of sincerity and diligence" and endeavored to awaken "public spirit" and elicit "cooperation." Additionally, Nakagawa said, "Here, young men should not only cultivate their individual character but also become aware of their duty as future members of local autonomy, so that they can become good citizens when the time comes" (Nakagawa, 1908, p. 17), identifying the YMA as "a training ground for future citizens" (Nakagawa, 1908, p. 17).

At the same time, Secretary Ushio Shigenosuke (Ushio), who was likewise a trustee and responsible for teaching about youth education at local improvement project courses with the Ministry of Home Affairs, said, "Local development is not easily achieved unless the young men are thus prepared, since they will be key figures in their respective local areas, regardless of whether they are directly involved in its administration or not" (Ushio, 1910 , p. 41), emphasizing that young men were promising bearers of local autonomy. He added, "If the young men lack a precise ideology of their municipalities and autonomy and have not undergone the appropriate training, it cannot be said that the Young Men's Association has fulfilled its ultimate aim, even if they were to have obtained new arithmetic knowledge at nightly study meetings or had contributed to industrial reform" (Ushio, 1910, p. 41). That is, regardless of how much knowledge the young men acquired, unless they came to understand the true meaning of autonomy, the Hotokukai's youth education would not have achieved its aims. Ushio finished with his hopes for the Hotokukai's youth education: "In brief, I want them to comprehend the true meaning of selfgovernance through communal life by performing work at a local organization of their own choice and at their own expense"' (Ushio, 1910, p. 41). In this 
way, Ushio argued that if young men could learn the true meaning of autonomy through "communal life" at the YMA, this would eventually foster “patriotism" (Ushio, 1910, p. 41), meaning loyalty to the state.

These views expressed by Ushio and Nakagawa framed youth education as "a means to autonomy education" and show how they tried to link YMA training to "national prosperity," which was one of the challenges of the postwar era. In other words, the primary purpose of the Hotokukai's youth education appears to have been "autonomy education" because, as Nakagawa stated, youth education "should not only benefit the individual youth but should greatly contribute to education in farm villages, to the encouragement of industry, to diligence and frugality, and to the cultivation of good conduct and good customs, not to mention the maintenance of public peace and municipal autonomy, in general"' (Nakagawa, 1908, p. 21).

The Hotokukai emphasized the cultivation of "a spirit of diligence" as an element supporting the abovementioned autonomy education. According to Hayakawa, "Sincerity, diligence, measured frugality, and solidary sharing are at the core of Hotoku, but among them I think diligence is the most needed, in this day and age" (Hayakawa, 1920, p. 10). Hojo Tokiyuki (Hojo), trustee and principal of Hiroshima Higher Normal School, offered the following view on the relationship between diligence and education in Hotoku-ism:

The doctrine of diligence immediately prized in this Hotoku teaching cannot be faked in the slightest in an education society, and there is no way for diligence to fluctuate at all. If diligence is applied, the outcome will be correspondent. If no diligence is applied, then the outcome lost will be correspondent to the inch. This effect of diligence on work is indeed solid and incapable of fluctuation, and it has the exact same effect on work in our education society. (Hojo, 1908, p. 12)

In this way, the Hotokukai emphasized the cultivation of a spirit of diligence in its efforts to teach young men to be the bearers of local autonomy. The Hotokukai wanted the young men to have an awareness of their identity as such bearers.

\section{Physical education in the Hotokukai's youth education}

In the Taisho period, the debate over the promotion of physical education for young men, spearheaded by Tanaka at the Army Ministry (Ono and Tomozoe, 2015; Takenoshita and Kishino, 1959), became more vigorous. This trend also became apparent in Shimin as the Hotokukai came to advocate the importance of promoting physical education for young men in its bulletin. How did the Hotokukai conceive of physical education in the context of the YMA's activities?

First, Sengoku Kotaro (Sengoku), a trustee involved in educating young men from farm villages in Shimane Prefecture as an engineer with the Ministry of Home Affairs, identified the building of physical strength as "a matter of necessity for young men" (Sengoku, 1914, p. 72) and then went on to state the following:

Agricultural work oftentimes involves physical exertion, and so sufficient results cannot be achieved in the absence of physical strength and an able body. Thus, it is necessary for the future to seek progress by devoting more energy to training and discipline. [...] Agricultural progress and advances in agriculturalists' physical strength must go hand in hand, and it very much is a way to improve the sturdiness of the nation. Young men in the farm villages should therefore not only engage in agricultural work and increase their physical strength but also contemplate training their bodies through ordinary recreational activities such as wrestling, jujutsu, fencing, pole-pushing, weightlifting, and seated wrestling. (Sengoku, 1914, p. 72)

Sengoku pointed to the example of agriculture and argued that agricultural progress and advances in agriculturalists' physical strength should "go hand in hand"; in other words, physical training was seen as a means to agricultural progress. In concrete terms, engaging in everyday recreational activities such as wrestling, jujutsu, fencing, polepushing, and weightlifting was encouraged as a way to better train the body and thus increase the fruits of agriculture. Additionally, the building of physical strength was seen as a prerequisite for everyday 
labor, as indicated by Sengoku's comment that "no matter how much knowledge one possesses, physical strength is indispensable for it to be applied in agricultural work"' (Sengoku, 1914, p. 72).

Furthermore, trustee and physician Takaki Kanehiro (Takaki) suggested in concrete terms that the physical strength of young men in the farm villages was diminishing:

In the past, one straw sack of barley was to hold a volume of eight $t o$, three $s h \bar{o}$, and five $g \bar{o}$ and a weight of 19 kanme. Moreover, one would not be considered a real farmer without the strength to load such a sack on a horse, yet at the present time, the weight was reduced to 18 kanme because it could not be carried, and again reduced to 15 kanme because it was still thought too heavy. This indicates that physical strength has weakened to such a degree that a sack of barley today weighs four kanme less than before. Moreover, the farmers of yesteryear would pound eight rounds of barley a day, but nowadays they can manage no more than six rounds. This means that work volume has gone down by a quarter. [...] At farms that employ many young men, no one is surprised at this discrepancy in farmers' physical strength. (Takaki, 1914, p. 15)

Takaki saw this measurable decline in physical strength among young men in the Taisho period compared to earlier generations as a problem, saying, "It is not difficult to imagine that [this decline] interferes with the progress of all work" (Takaki, 1914, p. 15). In other words, the decline of physical strength among young men was an issue that affected the basis of livelihood-labor-and young men ought to have a greater sense of crisis and take on the task of physical training.

Ushio and Nakagawa likewise expressed a sense of crisis in line with the arguments above that were based on young men's actual circumstances. Ushio was of the opinion that "it should be our most urgent task to stimulate various forms of exercise and martial arts like judo and fencing, as well as to encourage trekking in the wild, thereby increasing young men's physical strength and making them sturdy, risk-averse, and energetic" (Ushio, 1913, p. 24). Ushio emphasized the value of promoting exercise and physical education to not only build up physical strength but also increase the young men's energy.

By contrast, Nakagawa commented on the need to implement policies promoting not only young men's physical education but also moral and intellectual education (Nakagawa, 1915). This was based on the idea that "the foundation for promoting local autonomy lies in having the nation comprehend the principles of autonomy in all their forms" (Nakagawa, 1915, p. 54). Physical education was framed as an important means of promoting local autonomy and was associated with labor, a prerequisite for the basis of the livelihood that supported local autonomy. These arguments put forward by Ushio and Nakagawa show that the Hotokukai recognized the importance of physical education in youth education.

In summary, what the Hotokukai expected from its youth education was the cultivation of physical strength needed for labor, and they argued that the physical strength needed for labor should be secured through physical education. The reason for the Hotokukai's emphasis on the cultivation of physical strength among young men was the usefulness of physical education as a means of "training to endure the hardships of difficult manual labor" (Sengoku, 1914, p. 72) or fitness for everyday work. It is by studying this promotion of so-called "physical education contributing to actual lifestyle benefits," which linked "labor" and "physical education," that we may discover what characterized the physical aspects of the Hotokukai's youth education.

What significance did the Hotokukai's coupling of "labor" and "physical education" have in the social context of the time? As discussed, Japan, after the end of the Russo-Japanese War, sought an extensive reorganization of its domestic social system to adapt it to imperialism and prepare it for potential wars in the coming generation and swiftly restore the basis of its national livelihood to remedy the chaotic domestic situation and impending economic ruin. In particular, the continuous tax increases levied during the Russo-Japanese War had plunged municipal finances, the cornerstone of local societies, into disarray.

Looking at the Hotokukai's coupling of "labor" and "physical education," with reference to such social circumstances, allows us to identify it as a means to better understand the local improvement 
movement. We can then point to its relationship with "Hotoku-ism," the Hotokukai's core ideology, which figures in the background. The Hotokukai sought to inspire physical training among young men under the banner of Hotoku-ism and its reverence for the spirit of diligence, while, at the same time, aiming to restore local finances.

From the Hotokukai's perspective, the promotion of physical education in the YMA can be said to have been an attempt to develop young, ablebodied men capable of contributing to and enhancing the labor force by training their bodies through various exercises adapted to their everyday lives. This was driven by the domestic policy issue of increasing economic dynamism for the sake of "advancing our nation's [...] fortune."

\section{The Hotokukai's convening of the "Execu- tive council for the promotion of physical education" and its proposal of "Executive Matters for the Promotion of Physical Edu- cation",}

\subsection{Convening the "Executive Council for the Promotion of Physical Education",}

What vision did the Hotokukai have for young men as it was promoting physical education? In December 1914, the Hotokukai opened the "Executive Council for the Promotion of Physical Education", to investigate how to best promote physical education from the standpoint that its promotion "has a major relationship to the future fortune of this nation" (Hotokukai, 1915a, p. 18), for the population, in general, and young men, specifically. The executive council did not consist of specially trained members; Hotokukai trustees and external experts in various fields were invited to participate every time a meeting was held. As reports from the executive council meetings and statements made by the participants were published in Shimin, this paper uses clues from that source to summarize the main points relating to the council below.

The first executive council meeting was held on December 11, 1914, and invited trustees, as well as experts in physical education, education, and medicine.

First, Kano Jigoro (Kano), principal of the Tokyo Higher Normal School, Nakamura Haruji (Nakamura) from the Seikei Gakuen, and Hok- kaido governor Nishikubo Hiromichi (Nishikubo) gave their opinions from an educational standpoint. Kano (1915) indicated that it was essential for the general population to nurture an ideology that esteemed the body, since "national movements should be encouraged," $\mathrm{He}$ also argued for "the necessity of lifelong exercise"' (Kano, 1915, p. 20) including walking, running, swimming, judo, fencing, and other activities. Nakamura (1915) said, "We must build young men of sound mind" (Nakamura, 1915, p. 53), and argued that the cultivation of mental aspects should not be neglected when increasing young men's physical strength through various physical activities. Nishikubo (1915) introduced kendo as the best method of physical training.

Next, Ishihara Kikutaro (Ishihara), assistant professor in medicine at Tokyo Imperial University; Noda Tadahiro (Noda), from the Hygiene Bureau at the Ministry of Home Affairs; Kose Yasutoshi (Kose), from the Ministry of Education; and Takaki, former naval surgeon-general and medical researcher, gave their opinions from a medical standpoint. Ishihara (1915) argued that physical examinations and precautions against infectious diseases like trachoma and rubella should be thoroughly enforced. Noda (1915) introduced examples of health protection for poor children in the West, arguing that similar preventive measures should be put in place in Japan. Kose (1915) gave an overview of the physical status of young men, using statistical data from the Ministry of Education. Takaki (1915) argued that, based on the decline in youth fitness, present methods centering primarily on gymnastics were having an insufficient effect and that young men should actively engage in running, mountain climbing, and similar activities.

A second executive council meeting was held in January 1915. Like the previous occasion, medical scientists including Ishihara, Takaki, and Katayama Kunika, professor of medicine at Tokyo Imperial University, were also invited and offered advice on the significance of physical education from a medical point of view. In addition to the attendance of such experts in various fields, especially noteworthy was the participation of and comments by Tanaka from the Army Ministry. Tanaka (1915a) reported his observations from the West: "Cultivating our youth, the carriers of the nation's future, is a most urgent task from both the standpoints of national 
defense and the ideological health of society in general" (Tanaka, 1915a, p. 2), requesting that the Ministries of Home Affairs and Education develop youth education and invest in improving young men's fitness and constitutions. In addition, Tanaka spoke about youth education, saying, "It should be appropriate to cultivate fine men of healthy mind and body, worthy to be called true Japanese and furnished with the spirit of Japan"' (Tanaka, 1915a, p. 9), conveying the need he felt for the Army Ministry to systematically develop the education and instruction of the youth as carriers of the nation's future, together with the Ministries of Home Affairs and Education.

Nagai Domei (1915), a teacher at the Tokyo Higher Normal School and another first-time participant, requested that physical education be specified as one of the YMA's activities, saying, "It is my fervent desire to see Young Men's Groups across the country promote physical education as part of their activities" (Nagai, 1915, p. 14). He added that the first type of physical education to be promoted in the villages "ought to be manual labor, close to natural life in agriculture and industry, as this is the most appropriate" (Nagai, 1915, p. 15), and he further suggested that physical education could easily be pursued alongside labor activities, as emphasized by the Hotokukai. Moreover, he commented that physical education should never be relegated solely to the schools and that it should be practiced individually, so as to suit each and every person's situation.

Tanaka, from the Army Ministry, also participated in the third executive council meeting held on February 4, during which he advocated the need for youth physical education in even more concrete terms than before. Pressed to justify its necessity, he said, "Looking at the quality of the young men enlisted from year to year, thinking about their ability to fight, and considering the development of our nation's fortune in general, [...] vigorous physical strength lies at the core of everything" (Tanaka, 1915b, p. 13). He explained that the Army Ministry's interest in physical education was not strictly biased toward military preparatory training: "I am not saying that we should implement preparatory training for the military" (Tanaka, 1915b, p.15). In fact, he criticized the wholesale devotion to military preparation in French youth education and argued that youth physical education should be promoted in Japan only for the cultivation of sturdy minds and bodies, which in turn would function as a basic prerequisite for expanded troop education.

Even so, it could be argued that Tanaka's claims were simply an expedient. That is, it may be that Tanaka saw the executive council as a means to realize the military's request for youth education and therefore sought coordination with the Ministries of Home Affairs and Education. A more detailed examination of this point is needed, but $\mathrm{I}$ believe it is significant that Tanaka displayed a strong interest in such actions to the Ministries of Home Affairs and Education before the issuance of the first directive.

\subsection{The proposal of "Executive Matters for the Promotion of Physical Education"}

As discussed above, the Hotokukai invited experts in various fields to its executive council meetings and explored the ways and the meaning of promoting physical education, while gathering professional insights. According to the Hotokukai (1915b), the trustees should propose concrete executive matters to promote physical education, after listening to the experts' contentions. What executive matters did the executive council actually propose? In March 1915, the Hotokukai announced its "Executive Matters for the Promotion of Physical Education" in Shimin as a summary of the executive council's executive matters. It is not possible for us today to investigate how these were enacted by the trustees after the meetings, as that process is not described in Shimin or other bulletins and records, yet as the full text of the executive matters was published, I would like to examine it, in detail, below. The executive matters for physical education consisted of a total of 22 articles (Table 1).

Article 1 discussed the importance of fostering habits that respect a healthy and sturdy body and the awareness of one's national duty to maintain physical and mental health. Then, the concrete physical education methods of walking, running, swimming, kendo, and judo were encouraged. Group competition, in which large numbers could participate, was also encouraged, without any bias with respect to player organization. From a medical standpoint, sufficient nutritional intake and the prevention of infectious diseases were highlighted.

The following are three proposals characteristic 
Table 1 "Executive Matters for the Promotion of Physical Education".

1. To foster a habit of respecting a healthy and sturdy body, in general, as well as to be aware of one's national duty to maintain physical and mental health.

2. To promote walking in all its forms, as a common form of physical education for the nation, along with running, swimming, kendo, judo, and other activities.

3. It is common at metropolitan and local sports days to have only a few athletes in one or two specializations compete, while the rest are spectators. Here, victory should be determined by the overall results of each class or team, and a way should be devised for large numbers to feel responsible for their physical training.

4. It is extremely regrettable that athletes tend to abandon their important schoolwork before sports days and that schools tend to cancel all lessons in preparation for sports days. Victory should be awarded to those equally excellent in character and academic performance, thus rectifying the habit of not conferring this honor and the recent tendency of sports days to become a form of entertainment.

5. Care should be taken with the school dormitories, as well as balance and quality of food, in general, making proper nutritional intake a principal aim.

6. School hygiene should not stop at statistics, but attention should be paid to the students' physical health; not only should preventive measures be put in place for dreadful pulmonary tuberculosis and trachoma but greater care should be taken and the appropriate measures should be implemented to prevent the spread of infectious diseases that easily cause complications, such as measles and pertussis.

7. To promote Japan's traditional martial arts, such as kendo and judo, as ways to train body and mind, as well as to refrain from emphasizing temporary wins or losses and acts in form only, when it comes to matches and competitions, but to identify victors as those capable of accomplishing truly great goals by training mind and body and developing their determination.

8. Especially in the cities, the basics of national health should be established, with reference to measures now implemented in the West, such as summer camps for fragile children, outdoor education, and school facilities providing medical treatment and other supplies for youth from disadvantaged households.

9. When students are taken on school excursions, mental and physical training should be provided as much as possible, with reference to examples of youth camping practices in the West.

10. To revive shrine wrestling at Shinto shrines across the country, as well as to hold martial arts and sports competitions on festival days, involving the Local Soldiers' Association and the Young Men's Association.

11. The Young Men's Association should have physical checkups for its members once or twice a year, physical training should be conducted in preparation for the youth checkups, and local youth should be recognized for good results in the annual draft checkups.

12. The general meetings of the Local Soldiers' Association and the Young Men's Association should consist not only of speeches, lectures, and award ceremonies but should always include martial arts competitions in wrestling, kendo, judo, and target practice, among others, as well. Moreover, during excursions, students should widen their horizons and engage in labor commissioned as part of local public works.

13. To spread beneficial sports activities that go beyond mere games, in the form of professional competition, such as rope and farming competitions popular in agricultural regions.

14. Learning from the spirit of the Boy Scouts in the West, which is used a way to stimulate national energy, increase physical strength, and foster a future healthy population, Japan should also devise methods for youth instruction through the cooperation of all local improvement organizations, such as the existing Young Men's Association, the Local Soldiers' Association, the Farmers' Association, and the Education Association.

15. Instruction for boys and young men should not be biased toward military preparatory training but should be aimed at mental and physical health perceived broadly and the fostering of loyal citizens.

16. Japan's educational methods are extremely primitive and are still at an early stage compared to those of the advanced nations in the West, yet rather than suddenly devising ideal methods, we should first promote physical education methods practiced or easily practiced in the gymnastics and games of schools and all other organizations, cities, and municipalities.

17. Boys and young men of at least 14 years of age but not yet adults require institutions that provide physical education, in general. Municipalities should respond to this need by instituting officials or committee members in charge of physical education.

18. As much as possible and within budgetary limits, sports grounds or parks of all sizes that allow for sports should be built in the cities.

19. Besides engaging in their own professions, boys and young men in towns and villages should practice a particular sport with the Young Men's Association or the Local Soldiers' Association at least once a month, making use of the fields, grounds of shrines and temples, and elementary school sports fields.

20. In the big cities, specialized institutions should be created, especially to promote physical education, and research centers can be instituted to conduct research on physical education, centering on surveys.

21. When it comes to physical education, it is not enough to only pay attention to the boys and young men, but it is necessary to focus also on the fundamentals of character improvement. As the evils of alcohol abuse affect not only the person in question but can potentially cause degradation in his descendants, families and schools should caution boys and young men not to fall prey to such vices.

22. In brief, in both the cities and farm villages, the basis of able-bodiedness is the ability to perform labor independently without help, to use one's time efficiently, and to do a lot of work. Youth should be taught that the foundation for improving national health is to devote oneself to one's profession, learn the joys of diligence, and not shirk hard work.

(Compiled from “Executive Matters for the Promotion of Physical Education” [Hotokukai, 1915c, pp. 2-4]) 
of the promotion of physical education in the YMA.

The first was to think of youth training measures in various Western countries as models that Japan should learn from, as evidenced by these phrases: "with reference to measures now implemented in the West" (Article 8); "Learning from the spirit of the Boy Scouts in the West" (Article 14); and "Japan's educational methods are extremely primitive and are still at an early stage compared to those of the advanced nations in the West" (Article 16). The "Executive Matters" suggested that Japan should rethink its physical education, learn from the West, and promote youth physical education.

The second was to promote physical education with an eye toward its relationship to labor. Article 13 noted that it was important to promote "beneficial sports activities that go beyond mere games, in the form of professional competition, such as rope and farming competitions popular in agricultural regions." Physical education was promoted, in connection with the beneficial outcomes from labor.

The third was the specification that physical education was "not biased toward military preparatory training" for young men. Article 15 stated, "Instruction for boys and young men should not be biased toward military preparatory training but should be aimed at mental and physical health, perceived broadly, and the fostering of loyal nations." This suggests that the Hotokukai maintained a broad perspective of physical education and wished to promote it, without modeling it on or tailoring it for military preparatory training.

Finally, Article 22 concluded by stating, "In brief, in both the cities and the farm villages, the basis of able-bodiedness is the ability to perform labor independently without help, to use one's time efficiently, and to do a lot of work. The youth should be taught that the foundation for improving national health is to devote oneself to one's profession, learn the joys of diligence, and not shirk hard work." This exactly illustrates the "physical education contributing to actual lifestyle benefits" advocated by the Hotokukai, specifying that physical education should be developed with an eye to its relationship to labor. From the "Executive Matters," we can discern concretely the Hotokukai's vision for the promotion of physical education in the YMA.

Even so, the recommendations did not focus solely on physical education in the YMA. The contents and structure of the proposals were based on assertions made by individual participants at the aforementioned executive council meetings; at the same time, they revealed the vision of national and school physical education. The executive matters were concerned with promoting physical education for all of the nation's citizens, and the promotion of physical education in the YMA seems to have been perceived as an important and indispensable element for molding the promotion of physical education for the nation, as a whole.

\section{Summary and Matters for Future Study}

The results of this paper can be summarized, as follows:

1. The Hotokukai's emphasis on youth education was the pursuit of "autonomy education"- to prepare young men to shoulder future local societies. They emphasized the cultivation of a "spirit of diligence," which was at the core of Hotoku-ism, as a supportive element.

2. Characteristic of the physical education that was part of the Hotokukai's youth education was its coupling of "labor" and "physical education" and its promotion of "physical education contributing to actual lifestyle benefits." Physical education was understood to play a part in cultivating the elements necessary for everyday labor. A young man's "body," which was an important part of the labor force, was critical from the standpoint of strengthening the economic foundation; the Hotokukai connected it with increasing "economic dynamism," for the sake of "advancing our nation's [...] fortune."

3. The Hotokukai convened the "Executive Council for the Promotion of Physical Education" to consider ways to promote physical education. Trustees, as well as external experts in physical education, education, and medicine were invited. Tanaka, from the Army Ministry, also participated and argued that youth physical education should be promoted without bias toward military preparatory training and only as the cultivation of sturdy minds and bodies that could, in turn, function as a basic prerequisite for expanded troop education.

4. The Hotokukai summarized the results of the ex- 
ecutive council's meetings and announced them as "Executive Matters for the Promotion of Physical Education" in its bulletin, Shimin. These matters detailed the organization's vision of national and school physical education and the promotion of physical education in the YMA. There, the promotion of physical education in the YMA was presented as an important and indispensable element for molding the promotion of physical education on a national level.

This paper has clarified the Hotokudai's vision of physical education promotion in the YMA. How did this vision influence the reorganization of the YMA that came after the issuance of the first directive (1915) and the subsequent vitalization of physical education and sports activities? I address this point in this final section.

The first directive was issued on September 15, 1915, as a joint directive of the Ministries of Home Affairs and Education. It opened by specifying that "the youth organization is an institution for youth cultivation" (Ministry of Home Affairs and Ministry of Education, 1915, p. 1), thus stating that the YMA was a "cultivating institution" that made contributions to the state. In conjunction with this, it specified that they should prepare young men to be "healthy citizens" and "good citizens," in possession of a spirit and qualities to actively contribute to national development based on their recognition of the true meaning of loyalty.

The first directive then made explicit reference to "increasing physical strength," asking the YMA to promote physical education. On this point, the man who authorized the first directive, Minister of Home Affairs Ichiki (1916), talked about "training the body, inspiring a robust spirit, and practicing the virtues of diligence and sincerity" (Ichiki, 1916, p. 9), arguing that these were urgent matters for the future of youth education. He then explained the significance of improving vitality through physical training by linking it to its potential for "securing the nation's foundation and raising the nation's fortune" (Ichiki, 1916, p. 11). He identified the YMA's activities as dependent on everyday labor and emphasized that physical training was an element contributing to that labor (Ichiki, 1916). The statements by Ichiki about the first directive clearly alluded to the Hotokukai's coupling of "labor" and "physical education."
Moving on, how did the Hotokukai's vision influence the vitalization of the YMA's physical education and sports activities, following the issuance of the first directive? I answer this question based on insights from a preceding study (Ono and Tomozoe, 2015), which pointed to the leading role of governors, who were also Home Affairs bureaucrats in prefectural YMA policy. Ono and Tomozoe (2015) clarified that Inoue, in Tokyo, aimed to use physical education to foster "energetic young men that [could] make contributions in the labor force." Specifically, Inoue saw the promotion of physical education in the YMA as one solution to the challenges facing young workers in Tokyo and thought that its promotion could help nurture young men as "citizens spontaneously supporting the state."

The kind of promotion of physical education advocated by Inoue in Tokyo, which stressed the relationship between "labor" and "physical education," had similarities to the "physical education contributing to actual lifestyle benefits" promoted by the Hotokukai. In other words, we may infer that Inoue, who was also a Hotokukai trustee, attempted to realize the Hotokukai's vision in his role as governor. While this needs to be verified by carefully examining the situation in other prefectures, I do believe that the Hotokukai's vision for the promotion of physical education in the YMA laid the groundwork for the YMA's physical education promotion policies that came after the issuance of the first directive.

Future studies need to examine the circumstances in other prefectures, as discussed above, but they must also clarify the kinds of YMA physical education promotion policies enacted by governors who were also Hotokukai trustees. We should also think about a deeper examination of the visions of individual Home Affairs bureaucrats such as Ichiki or Inoue. Such efforts should shed more light on the influence of the Ministry of Home Affairs on the development of the YMA's physical education promotion policies.

\section{Notes}

*1 Past research has suggested that the designation of this youth organization was standardized as "YMA," after the issuance of the first directive in 1915 (Tanaka, 1988). The organization had gone under a variety of names prior to that, such as the "Young Men's Group" and the "Young Men's Association." In fact, the names appearing in the 
Shimin, which is the principal source for this paper, differ according to the author. Because of this, I have decided to unify the organization's name as the "YMA," unless otherwise specified.

*2 "Meiji" and "Taisho" are Japanese era names (corresponding to the system of one era name per Emperor). Meiji era extended from January 25, 1868, to July 30, 1912, and Taisho era extended from July 30, 1912, to December 25, 1926.

*3 Between 1871 and 1946, governors were officials dispatched by the Ministry of Home Affairs.

*4 The Local Governors' Council did not issue specific guidelines on the promotion of physical education in the YMA to the prefectural governments, leaving the task of realizing policies to those governments (Ono and Tomozoe, 2015).

*5 Education-related administration has traditionally been handled by the Ministry of Education, yet prior to the end of the Russo-Japanese War, the Ministry had neglected social education and had essentially not conducted any policy-making (Fuwa, 1990; Miyahara, 1990). In contrast, it was the Ministry of Home Affairs that discovered the bottleneck in social education that obstructed the development of the local improvement movement. Thus, my focus in this paper is on the Ministry of Home Affairs.

*6 The Hotokukai was renamed the "Central Hotokukai" in 1912, but I have decided to unify it as "Hotokukai," unless otherwise specified.

*7 Besides Inoue, other Hotokukai trustees, including Nakagawa Nozomu (Yamaguchi, Kagoshima, Osaka) and Seino Chotaro (Hyogo) also served as governors.

*8 According to the Hotokukai (1906b), the Hotokukai consisted of trustees and a small number of secretaries. The number of trustees was great, numbering 79 in 1909 and 103 in 1915; Table 2 contains a selection of trustees who were involved in the founding of the Hotokukai or who otherwise played key roles in its organization and management. It shows their affiliations and positions when the Hotokukai was founded (1906).

*9 The Hotoku, created and advocated by Ninomiya Sontoku (1787-1856), a late Edo agricultural administrator, included teachings concerning farmers' way of life. According to Tomita Kokei (1856), Ninomiya's leading disciple, Hotoku thought consisted of four parts: (1) sincerity as the root; (2) diligence as the master; (3) measured frugality as the body; and (4) solidary sharing as the action (Tomita, 1856, p. 4). Here, "sincerity" means dealing with matters with a true heart and cultivating a sincere mind; "diligence" means humbly engaging in labor, refining one's wisdom through that labor, and improving oneself; "measured frugality" means adapting one's expenses to one's income; and "solidary sharing" means giving away the excess that remains after "measured frugality" to benefit one's future self, one's descendants, and one's village, area, and country. In this way, the Hotoku thought advocated by Ninomiya established self-control through an abstemious life ethic and sought to improve individual life and farm village society, as a whole, by reforming everyday conduct centered on production activities. Hotoku thought was a farmer's ideology aimed at reviving destitute villages in the final decades of the early modern period (Kano, 1967). The feudal lords of the late early-modern period adopted Hotoku thought as a way to reform administrative finances
Table 2 Trustees of Hotokukai (Excerpt).

\begin{tabular}{cl}
\hline Name & \multicolumn{1}{c}{ Main Occupation } \\
\hline $\begin{array}{c}\text { Ichiki } \\
\text { Kitokuro }\end{array}$ & Undersecretary, the Ministry of Home Affairs \\
\hline $\begin{array}{c}\text { Inoue } \\
\text { Tomoichi }\end{array}$ & $\begin{array}{l}\text { Director, the Prefectural Division of the Minis- } \\
\text { try of Home Affairs Bureau of Regional Affairs }\end{array}$ \\
\hline $\begin{array}{c}\text { Okada } \\
\text { Ryohei }\end{array}$ & $\begin{array}{l}\text { Member, the House of Peers and Official of the } \\
\text { Ministry of Education }\end{array}$ \\
\hline $\begin{array}{c}\text { Kume } \\
\text { Kinya }\end{array}$ & $\begin{array}{l}\text { Chief of a Bureau, the Ministry of Agriculture } \\
\text { and Commerce }\end{array}$ \\
\hline $\begin{array}{c}\text { Kuwata } \\
\text { Kumazo }\end{array}$ & Member, the House of Peers \\
\hline $\begin{array}{c}\text { Seino } \\
\text { Chotaro }\end{array}$ & $\begin{array}{l}\text { Director, the Town and Village Division of the } \\
\text { Ainistry of Home Affairs Bureau of Regional }\end{array}$ \\
\hline $\begin{array}{c}\text { Tokonami } \\
\text { Takejiro }\end{array}$ & $\begin{array}{l}\text { Director, the Local Station of the Ministry of } \\
\text { Home Affairs }\end{array}$ \\
\hline Tomeoka & $\begin{array}{l}\text { Temporary Employee, the Local Station of the } \\
\text { Kosuke }\end{array}$ \\
\hline $\begin{array}{c}\text { Nakagawa } \\
\text { Nozomu }\end{array}$ & $\begin{array}{l}\text { Secretary, the Local Station of the Ministry of } \\
\text { Home Affairs }\end{array}$ \\
\hline
\end{tabular}

Hayakawa

Senkichiro

Executive Director, Mitsui Bank

(Summarized from using "Trustees of Hotokukai and Department of Home" (Hotokukai, 1909, pp. 4-5))

and implemented it as a movement for self-restoration.

*10 The local improvement movement courses were organized by the Ministry of Home Affairs and provided general and administrative instruction for local leaders in all areas, including local general administration, municipal finances, public works, education, hygiene, agriculture, forestry, and industrial associations. The courses were primarily taught by Home Affairs bureaucrats but also experts and bureaucrats from the Ministries of Education and Agriculture and Commerce. According to reports from the Local Bureau of the Ministry of Home Affairs (1909), a variety of lectures and speeches were given on topics such as "The Meaning of Autonomy" (Ichiki), "Autonomy and Economy" (Nakagawa), "The Unification and Use of Village Assets" (Yuasa Kurahei), "Autonomy and the Young Men's Group" (Ushio), "Projects for Moral Reform and the Cultivation of Virtue" (Nakagawa), and "Farm Village Reform and Volunteers"' (Tomeoka).

\section{References}

Fuwa, K. (1990). Kindai nihon no kokka to seinen kyoiku [Modern Japanese nation and youth education]. Tokyo: Gakubunsha, p. 35. (in Japanese).

Hayakawa, S. (1920). Tada funrei doryoku arunomi [Make a violent effort]. Shimin., 15(4): 10-11. (in Japanese).

Hayata, T. (2014). Hotoku shiho to kinsei shakai [Hotoku shiho and modern society]. Tokyo: Tokyodo Publishing, p. 
12. (in Japanese).

Hojo, T. (1908). Kinro zammai no kyokai [Boundaries of labor]. Shimin., 3(11): 11-14. (in Japanese).

Hotokukai. (1906a). Kaikan no ji [Opening remarks]. Shimin., 1(1): 1-4. (in Japanese).

Hotokukai. (1906b). Hotokukai soku taiko [Hotokukai constitution outline]. Tokyo: Hotokukai, p. 9. (in Japanese).

Hotokukai. (1909). Honkai hyogiin oyobi kateibu hyogiin [Councilors of the Hotokukai and Councilors]. Shimin., 4(12): 4-5. (in Japanese).

Hotokukai. (1915a). Taiiku shorei ni kansuru jikko jiko kyogikai [Executive Council for the Promotion of Physical Education]. Shimin., 9(10): 18. (in Japanese).

Hotokukai. (1915b). Dai 2 kai taiiku shorei ni kansuru jikko jiko kyogikai [ $2^{\text {nd }}$ Executive Council for the Promotion of Physical Education]. Shimin., 9(11): 24. (in Japanese).

Hotokukai. (1915c). Taiiku shorei ni kansuru jikko jiko kyogikai [Executive Matters for the Promotion of Physical Education]. Shimin., 9(12): 2-4. (in Japanese).

Ichiki, K. (1907). Dotoku keizai icchi no taii [Majority of morality and economic accord]. Shimin., 2(10): 18-24. (in Japanese).

Ichiki, K. (1916). Seinendan no toitsu [Unification of Young Men's Association]. Teikoku Seinen, 1(1): 9-11. (in Japanese).

Ichiki, K. (1920). Sokan 15 nen ni sairite [To celebrate the first 15 years]. Shimin., 15(4): 8-9. (in Japanese).

Inoue, T. (1909). Jisei ni tekigo seru hotoku no oshie [The teachings of Hotoku adapting to the times]. Shimin., 4(2): 17-19. (in Japanese).

Inoue, T. (1916). "Shimin" 10 nen no aidokusha ni kansha suru [I thank the 10 years' admirer of "Shimin'”]. Shimin., 11(1): 10-14. (in Japanese).

Ishida, Y. (1954). Meiji seiji shiso shi kenkyu [A study on the history of Meiji Political thought]. Tokyo: Miraisha, p. 86. (in Japanese).

Ishihara, K. (1915). Gakko eiseijo no 4 yoten [Four main points on school hygiene]. Shimin., 9(10): 35-37. (in Japanese).

Kano, M. (1964). Meiji koki ni okeru kokumin soshikika no katei [Process of nation organization in the late Meiji era]. Shikan., 69: 18-46. (in Japanese).

Kano, M. (1967). Sengo keiei to noson kyoiku: Nichiro sensou go no seinendan undo ni tsuite [Postwar management and rural education: About the Young Men's Associations movement after the Russo-Japanese War]. Shiso, 52:42-59. (in Japanese).

Kano, J. (1915). Kokumin undo wo shorei seyo [Encourage national movement]. Shimin., 9(10): 19-26. (in Japanese).

Kinoshita, H. (1970). Supotsu no kindai nihonshi [Modern Japanese history of sports]. Tokyo: Kyorin Shoin, p. 201. (in Japanese).

Kose, Y. (1915). Gakusei no hatsuiku oyobi kenko jotai [Student development and health]. Shimin., 9(10): 55-60. (in Japanese).

Kozu, M. (1994). Nihon kindai supotsu shi no teiryu [Undercurrent of the history of modern sports in Japan]. Tokyo: Soubun Kikaku, p. 181. (in Japanese).

Kumagai, T. (1942). Dai Nihon seinendan-shi [History of Japanese Young Men's Associations]. Tokyo: Nihon Seinenkan, p. 114. (in Japanese).

Local Bureau of the Ministry of Home Affairs. (1909). Chiho kairyo jigyo koen jokan [Lecture of regional improvement projects Vol.1]. Tokyo: Hakubunkan, p. 21. (in Japanese).
Local Bureau of the Ministry of Home Affairs. (1911). Chiho keiei shokan [Regional management small book]. Tokyo: Hotokukai, p. 56. (in Japanese).

Ministry of Home Affairs and Ministry of Education. (1915). Seinen dantai no shido hattatsu ni kansuru ken [Matter of the instruction development of the Young Men's Associations]. Official Gazette, 937: 1. (in Japanese).

Miyahara, S. (1990). Shakai kyoiku ron [Theory of the social education]. Tokyo: Kokudosha, p. 103. (in Japanese).

Miyaji, M. (1973). Nichiro sengo seiji-shi no kenkyu: Teikoku shugi keiseiki no toshi to nomin [A study of the Russo Japanese postwar political history: Cities and farmer of the imperialism formative period]. Tokyo: University of Tokyo Press, p. 26. (in Japanese).

Nagai, D. (1915). Taiiku no hongi to shorei no hoho [Method of principle and encouragement in physical education]. Shimin., 9(11): 11-16. (in Japanese).

Nakagawa, N. (1908). Nouson jichi to seinen dantai [Rural autonomy and youth organizations]. Shimin., 2(11): 16-21. (in Japanese).

Nakagawa, N. (1915). Chiho kaihatsu jo jikko wo kisubeki yonji [Four items to be executed in rural development]. Shimin., 10(3): 52-55. (in Japanese).

Nakamura, S. (1915). Kokoro to karada wo shitashiku seyo [Keep your mind and body closer together]. Shimin., 9(10): 51-54. (in Japanese).

Namimatsu, N. (2004). The change of Houtoku Touhgt and the subject of national policy: Through the community development policy in Kyoto Prefecture. J. Kyoto Sangyo Univ., 31: 56-77. (in Japanese).

Nishikubo, H. (1915). Kendo ha sairyo no taiikuho nari [Kendo is the best physical education method]. Shimin., 9(10): 38-42. (in Japanese).

Noda, T. (1915). Mazu jido no kenko wo hogo seyo [Protect the health of the child]. Shimin., 9(10): 43-49. (in Japanese).

Oe, S. (1974). Kokumin kyoiku to guntai [National education and military]. Tokyo: Shin Nihon Shuppan, p. 35. (in Japanese).

Ono, Y. and Tomozoe, H. (2014). Sporting activities of the Young Men's Association during the period between the Taisho era and pre-war Showa era: An analysis of the Fuchu Sport bulletins. Jpn. J. Phys. Educ. Health Sport Sci., 59: 705-720. (in Japanese).

Ono, Y. and Tomozoe, H. (2015). Studies on Physical Education Promotion Policy for Young Men's Association in the Taisho Era: Focusing on the administrative process in Tokyo Prefecture. Jpn. J. Phys. Educ. Health Sport Sci., 60: 449-465. (in Japanese).

Oshima, M. (1959). Development of local government in the late Meiji Period: Regional improvement movement. The Memoirs of the Institute for Advanced Studies on Asia. 19: 79-126. (in Japanese).

Oshima, M. (1998). Regional integration policy during the First World War: Focusing on the claim of the magazine "Shimin". Senshu Shigaku, 29: 1-49. (in Japanese).

Sakata, M. (1972). Kaidai [Bibliographical introduction]. Institute of internal affairs and Japan Modern History Study Group(ed.) Shimin mokuji soran [Contents overview of “Shimin"]. Tokyo: Ryukei Shosha, pp. 1-19. (in Japanese). Sasaki, H. (2000). The emergence of local Young Men's Association competitions in Taisho period: from the case of Ishikawa Prefecture Youth Sports Festival Taisho 7-10. Jpn. J. Hist. Phys. Educ. Sport, 17: 1-13. (in Japanese). 
Sasaki, H. (2004). The understandings of young men toward sport in the farming village during the agricultural crisis (1925-1935). Jpn. J. Hist. Phys. Educ. Sport, 21: 15-25. (in Japanese).

Sengoku, K. (1914). Nouson seinen no shuren [Training of rural youth]. Shimin., 9(1): 70-73. (in Japanese).

Suzuki, K. (1909). Keizai shicho to hotoku shugi [Economic thought and Hotokuism]. Shimin., 4(1): 56-61. (in Japanese).

Taikakai. (1971). Naimusho shi dai 4 Kan [Histry of Ministry of Home Affairs Vol. 4]. Tokyo: Hara Shobo, p. 345. (in Japanese).

Takaki, K. (1914). Tairyoku no zoshin to bundo no genshu [Promotion of physical strength and strict observance of status]. Shimin., 9(4): 15-16. (in Japanese).

Takaki, K. (1915). Taii no geraku to sono kojo saku [Physique decline and improvement measures]. Shimin., 9(10): 27-34. (in Japanese).

Takenoshita, K. and Kishino, Y. (1959). Kindai nihon gakko taiikushi [History of school physical education in modern times of Japan]. Tokyo: Toyokan Shuppansha, p. 104. (in Japanese).

Tanaka, G. (1915a). Rekkyo ni okeru shonen gundan no genjo [Current situation of juvenile corps in the great powers country]. Shimin., 9(11): 2-10. (in Japanese).

Tanaka, G. (1915b). Chiho seinendanin ni nozomu [Hope for regional Young Men's Association members]. Shimin., 9(12): 13-17. (in Japanese).

Tanaka, H. (1988). Gakko gai kyoiku ron [Education theory of outside the school]. Tokyo: Gakuyo Shobo, p. 88. (in Japanese).

Tomeoka, K. (1914). Hotokukai no shimei [Mission of the Hotokukai]. Shimin., 8(10): 38-41. (in Japanese).

Tomeoka, K. (1922). Sokan toji wo omou [Remember the first time]. Shimin., 17(5): 37-39. (in Japanese).

Tomita, K. (1856). Hotoku ki [Record of Hotoku]. Tokyo: Dinihon Nokai. (in Japanese).

Ushio, S. (1910). Seinen to aikyoshin [Youth and one's spiritual home]. Shimin., 5(2): 39-41. (in Japanese).

Ushio, S. (1913). Seinen ni taisuru kibo 2 soku [Two hopes for youth]. Shimin., 8(4): 24-28. (in Japanese).

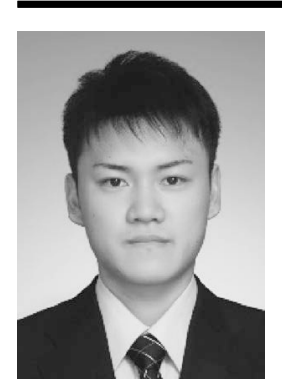

Name: Yuta Ono

Affiliation:

Faculty of Sport Sciences, Waseda University

Address:

2-579-15 Mikajima, Tokorozawa, Saitama 359-1192, Japan

Brief Biographical History:

Apr 2016- Mar 2018 Research Associate of Faculty of Sport Sciences, Waseda University

Apr 2018-Mar 2019 Assistant Professor of Faculty of Sports Sciences, Waseda University

Apr 2019- Lecturer of Faculty of Sports Sciences, Waseda University

Main Works:

- Ono, Y. and Tomozoe, H. (2014). Sporting activities of the Young Men's Association during the period between the Taisho era and pre-war Showa era: An analysis of the Fuchu Sport bulletins. Jpn. J. Phys. Educ. Health Sport Sci., 59: 705-720. (in Japanese)

- Ono, Y. and Tozmoeoe, H. (2015). Studies on Physical Education Promotion Policy for Young Men's Association in the Taisho Era: Focusing on the administrative process in Tokyo Prefecture. Jpn. J. Phys. Educ. Health Sport Sci., 60: 449-465. (in Japanese)

-Ono, Y., Tomozoe, H., and Nemoto, S. (2017). A study on the Formation Process of Sports Recommendation Admissions to Universities in Japan. Jpn. J. Phys. Educ. Health Sport Sci., 62: 599-620. (in Japanese)

-Ono, Y., Tomozoe, H., Takahashi, S., Fukami, E., Yoshinaga, T., and Nemoto, S. (2018). Conceptions of learning and learning strategies of students in junior high school physical education. Jpn. J. Phys. Educ. Health Sport Sci., 63: 215-236. (in Japanese)

Membership in Learned Societies:

- Japan Society of Physical Education, Health and Sport Sciences

- Japanese Society of Sport Education

- Japanese Association of Educational Psychology

- Japan Society for the Pedagogy of Physical Education

-Japan Society for the Philosophy of Sport and Physical Education 